\title{
SC Hemoglobinopathy (HbSC) with Osteoarticular Complications: Case Report
}

\author{
Filipe Bezerra Macedoํㅜ, Jucier Gonçalves Júnior², Fabiana Gouveia Guimarães³, \\ Raphael Cisne Tomaz ${ }^{3}$, Débora Valentim Monte Alto², Paula Pessoa Pinheiro², \\ Jácia Maria Neves Coelho ${ }^{1}$
}

\author{
${ }^{1}$ Department of Pediatric, Hospital Maternidade São Vicente de Paulo (HMSVP), Barbalha, Brazil \\ ${ }^{2}$ School of Medicine, Federal University of Cariri (UFCA), Barbalha, Brazil \\ ${ }^{3}$ Residence in Pediatrics, Federal University of Cariri (UFCA), Barbalha, Brazil \\ Email: juciergjunior@hotmail.com
}

How to cite this paper: Macedo, F.B. Júnior, J.G., Guimarães, F.G., Tomaz, R.C., Alto, D.V.M., Pinheiro, P.P. and Coelho, J.M.N. (2017) SC Hemoglobinopathy (HbSC) with Osteoarticular Complications: Case Report. Health, 9, 1075-1080.

https://doi.org/10.4236/health.2017.97078

Received: April 24, 2017

Accepted: July 17, 2017

Published: July 20, 2017

Copyright $\odot 2017$ by authors and Scientific Research Publishing Inc. This work is licensed under the Creative Commons Attribution International License (CC BY 4.0).

http://creativecommons.org/licenses/by/4.0/

\begin{abstract}
Background: Among hemoglobinopathies, the most prevalent in our population are hemoglobins $\mathrm{S}$ and $\mathrm{C}$, which are capable of producing disease when homozygous. In cases of double heterozygotes with sickle hemoglobin C (SC), the disease is less expressive in its clinical condition and rarer. Case report: Patient has a previous hospitalization with pain in the joints in knee and hip and several febrile peaks. Upon physical examination, the patient had difficulty in walking, without edema, pedal and tibial posterior pulses present, with no signs of compartment syndrome. Complementary exams revealed anemia, leukocytosis and lymphopenia. The hemoglobin electrophoresis showed the SC Hemoglobinopathy. The treatment with antibiotic therapy according to the protocol (Oxacillin and Ceftriaxone) was restarted and submitted to joint drainage in affected limb. Conclusion: Osteomyelitis and septic arthritis in patients in the pediatric age group should be considered as serious infections that deserve hospitalization and more expressive treatment.
\end{abstract}

\section{Keywords}

SC Hemoglobinopathy, Paediatrics, Case Report

\section{Introduction}

Hemoglobinopathies are a group of hereditary diseases first described in 1910 by Herrick when investigating black patients with the disease who had anemia, abdominal pain and joint pain [1].

Among hemoglobinopathies, the most prevalent in our population are hemoglobins $\mathrm{S}$ and $\mathrm{C}$, which are capable of producing disease when homozygous. 
However, when heterozygous, the carrier is clinically asymptomatic, showing no disease and no anemia [2].

Sickle cell anemia affects about 100,000 individuals in the United States, and approximately two million Americans carry the sickle cell trait [3]. A recent study estimated that about 305,800 babies were born with Sickle Cell Anemia in 2010, of which two-thirds were in Africa. The outlook is that, on average, there is an increase of $25 \%$ of cases, reaching a total of 404,200 individuals in 2050 [4].

Inheriting the Sickle Cell Anemia gene from both parents results in homozygous (SS) sickle cell disease which is usually severe [5]. Hemoglobinopathy $\mathrm{C}$ is considered a benign condition. However, there is evidence that this pathology can cause serious problems [6]. In cases of double heterozygotes with sickle hemoglobin C (SC), the disease is less expressive in its clinical condition [5] and rarer.

Therefore, due to the rarity of the nosological entity and its importance to the academic community, it was aimed to discuss a case of patient affected by SC Hemoglobinopathy, who presented osteomyelitis and septic arthritis.

\section{Case Report}

S.L.B, 04 years and 04 months, male, black, born and raised from Barbalha, in the state of Ceará, Brazilian Northeast, previously diagnosed with SC hemoglobinopathy, septic arthritis and chronic osteomyelitis in the right knee.

Neonatal history: born cesarean birth, and then phototherapy for 2 hours. Exclusive breastfeeding up to six months and mixed up to 03 years. Vaccination scheme as recommended by the Brazilian Ministry of Health, without presenting any reactions. Development Neuropsychomotor (DPNM) suitable for age. Parents have no history of consanguinity.

Patient has a previous hospitalization with pain in the joints in knee and hip and several febrile peaks. Upon physical examination, the patient had difficulty walking, without edema, pedal and tibial posterior pulses present, with no signs of compartment syndrome. He used Cephalotin for seven days, was released home with Cephalexin for 10 days. There was no improvement in the febrile condition and it evolved with phlogistic signs in the right knee.

Returned to service with maintenance of clinical and RX showing important osteomyelitis in his right knee (Figure 1). Complementary exams revealed anemia, leukocytosis and lymphopenia in hemogram (HMG) of admission (November $\left.4^{\text {st }}, 2016\right)$. And the right knee Ultrasonography (USG) performed at admission evidenced joint cavity with irregular and thickened cartilage with a discrete fluid collection compatible with right knee arthritis.

The treatment with antibiotic therapy according to the protocol (Oxacillin and Ceftriaxone) was restarted and submitted to joint drainage in affected limb. It evolved with episodes of intense pain in the right knee that improved to the use of Tramadol and progressively were diminishing throughout the hospitalization. After the initiation of treatment was observed improvement hematimetric patterns (Table 1), the hemoglobin electrophoresis pattern (Table 2), the ESR and CRP (Table 3). 


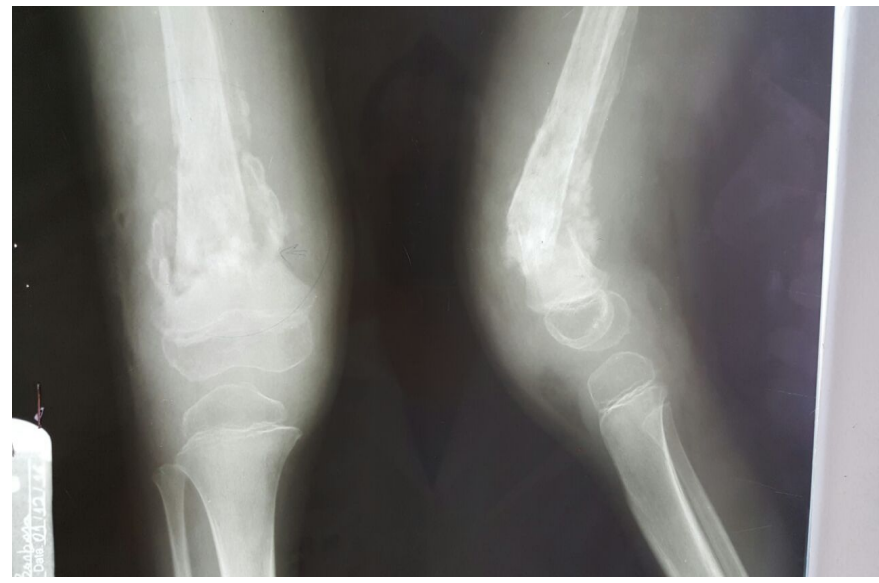

Figure 1. RX showing important osteomyelitis in his right knee.

Table 1. Serial Hemograms $\left(\mathrm{cel} / \mathrm{mm}^{3}\right)$.

\begin{tabular}{|c|c|c|c|c|c|c|c|c|c|c|c|c|c|c|c|}
\hline Data/HMG & Leuc & $\begin{array}{c}\text { Neut } \\
(\%)\end{array}$ & $\begin{array}{l}\text { Seg } \\
(\%)\end{array}$ & $\begin{array}{l}\text { Eos } \\
(\%)\end{array}$ & $\begin{array}{l}\text { Bast } \\
(\%)\end{array}$ & $\begin{array}{l}\text { Linf } \\
(\%)\end{array}$ & $\begin{array}{l}\text { Mon } \\
(\%)\end{array}$ & $\begin{array}{c}\text { Plt } \\
\left(10^{3}\right)\end{array}$ & $\begin{array}{c}\mathrm{Hb} \\
(\mathrm{g} / \mathrm{dl})\end{array}$ & $\begin{array}{l}\mathrm{Ht} \\
(\%)\end{array}$ & $\begin{array}{c}\text { Hem } \\
\left(10^{6} / \mathrm{mm}^{3}\right)\end{array}$ & $\begin{array}{c}\text { VCM } \\
(\mathrm{fl})\end{array}$ & $\begin{array}{c}\mathrm{HCM} \\
(\mathrm{pg})\end{array}$ & $\begin{array}{l}\text { CHCM } \\
(\mathrm{g} / \mathrm{dL})\end{array}$ & $\begin{array}{c}\text { RDW } \\
(\%)\end{array}$ \\
\hline $29 / 08 / 13$ & 16,800 & 33 & 68 & 6 & 0 & 80 & 336 & 427 & 9.2 & 30.1 & 3.72 & 80.9 & 24.7 & 30.6 & 17.8 \\
\hline $04 / 05 / 14$ & 13,800 & 70 & 69 & 2 & 0 & 44 & & 212 & 7.0 & 20.7 & - & 64.1 & 21.7 & 33.8 & 17.4 \\
\hline $28 / 04 / 14$ & 16,500 & 82 & 80 & 1 & 0 & 62 & 660 & 540 & 9.2 & 27.6 & - & - & - & - & - \\
\hline $12 / 07 / 14$ & 12,500 & 82 & 79 & 0 & 3 & 14 & 4 & 300 & 9.6 & 27.6 & 3.59 & 76.9 & 26.7 & 34.8 & 17 \\
\hline $21 / 11 / 14$ & 11,600 & 22 & 22 & 11 & 0 & 59 & 3 & 330 & 9.6 & 30 & 4.01 & 74.8 & 23.9 & 32 & 21.8 \\
\hline $29 / 01 / 15$ & 10,300 & - & 54 & 2 & 0 & 40 & 4 & 433 & 8.5 & 27 & 3.82 & 72.6 & 22.2 & 30.6 & 20 \\
\hline $04 / 11 / 16$ & 21,500 & - & - & - & - & - & - & 551 & 10.6 & 32.4 & 4.29 & - & - & - & - \\
\hline $10 / 11 / 16$ & 11,700 & - & 70 & & 1 & 22 & - & 470 & 8.2 & 25.3 & - & - & - & - & - \\
\hline
\end{tabular}

Legend: Leuco-Leukocytes. Neut-Neutrophilis. Seg-Segmented. Eos-Eosinophils. Bast-Blood Counts. Linf-Lymphocytes. Mon-Monocytes. PltPlatelets. Hb-Hemoglobin. Ht-Hematocrit. Hem-Red blood cells. VCM-Mean corpuscular volume. HCM-Corpuscular Hemoglobin Concentration. CHCM-Mean corpuscular hemoglobin concentration. RDW-Red Cell Distribution Width.

Table 2. Hemoglobin Electrophoresis.

\begin{tabular}{cccccc}
\hline Datas & A1 (\%) & A2(\%) & F(\%) & S(\%) & C(\%) \\
\hline $10 / 09 / 13$ & 4.7 & 4.4 & 2.4 & 46.7 & 41.8 \\
$19 / 10 / 13$ & 0.3 & 3.9 & 2.2 & 48.7 & 44.9 \\
$18 / 03 / 14$ & 10.7 & 3.6 & 1.3 & 43.9 & 40.5 \\
$24 / 08 / 15$ & 0.0 & 3.5 & 1.0 & 50.2 & 45.3 \\
\hline
\end{tabular}

Legend: Fetal portion of hemoglobin (F); A1 portion of Hemoglobin (A1); A2 portion of hemoglobin (A2); $S$ portion of hemoglobin (S); C portion of Hemoglobin (C).

Table 3. Laboratory Exams and their dates.

\begin{tabular}{cccccc}
\hline Data & HSV & CRP & DB & IB & TB \\
\hline $29 / 08 / 13$ & - & - & 0.21 & 0.48 & 0.69 \\
$12 / 07 / 14$ & 5 & - & - & - & - \\
$04 / 11 / 16$ & 3 & 50 & - & - & - \\
$10 / 11 / 16$ & 96 & 74 & - & - & - \\
\hline
\end{tabular}

Legend: Hemosedimentation volume (HSV); C Reactive Protein (CRP); Total Bilirubin (TB); Direct Bilirubin (DB); Indirect Bilirubin (IB). 
Patient was discharged after completion of antibiotic therapy and clinical improvement, being able to return to their activities.

\section{Discussion}

Sickle cell disease is a group of genetic diseases that is especially prevalent in tropical and subtropical regions [7] caused by inheritance of $\mathrm{HBB}$ mutations due to sickle hemoglobin (HbS mutation, HBB E6V) in homozygous form (Sickle Cell Anemia, HbSS) or as a composite heterozygote with another abnormal hemoglobin (e.g. HbSC, HbS $\beta$ talh) [8].

Forced migration and the continuous movement of the population have spread throughout the world, with birth rates estimated at 0.49 per 1000 in the Americas, 0.07 per 1000 in Europe, 0.68 per 1000 in South and Southeast Asia and 10.68 per 1000 in Africa [7]. The prevalence of hereditary anemias in the population varies among Brazilian regions, since it is closely linked to the process of ethnic formation of each one [2].

Studies in Brazil show the high prevalence of heterozygotes for $\mathrm{HbS}$ and $\mathrm{HbC}$ [9], especially in Afro-descendants ranging from 6.9\% to $14.5 \%$ [2] [10]. This is in accordance with this case.

In 1987, the largest study of prevalence and distribution of hemoglobinopathies in Brazil showed that $74.12 \%$ of the sample population had HbAS, HbSS or HbSC mutation [11]. In the State of Pernambuco, Brazil, it was observed that $0.6 \%$ of the infants analyzed had $\mathrm{HbAC}$ and $5.3 \%$ presented $\mathrm{Hb} \mathrm{S}$; of this last percentage, $97.1 \%$ had HbAS and $2.9 \%$ had HbSC [12].

Typically, HbSC disease is similar to sickle cell disease (Squires, 2016) characterized by chronic anemia and vaso-occlusive and hemolytic complications acute and chronic [8]. Examples of such complications are pain or vaso-occlusive crises, aplastic crisis, cutaneous pallor, jaundice, chronic anemia, hand-foot syndrome, ulcers in the lower limbs, splenic sequestration, with increased amount of blood in the liver and spleen, which leads to a decrease in circulating blood volume [13].

However, these manifestations are milder and have a lower frequency, which gives HbSC patients a longer life expectancy [14]. It is interesting to note that septic arthritis or even osteomyelitis itself are not often cited as direct and common consequences of HbSC, giving the case an interesting aspect to the study. In 2012, a study carried out at the Escola Paulista de Medicina, São Paulo, Brazil, reports three cases in a sample of 21 patients presenting hemoglobinopathy as the underlying disease of bone infections [15].

Osteonecrosis, especially in the shoulder, occurs with almost equal frequency between HbSC and HBSS and the Acute Thoracic Syndrome (ATS) and may have increased mortality in HbSC disease [14]. Aseptic necrosis of the femoral head is related to episodes of acute thoracic syndrome due to fatty embolism [2], justifying the importance in the diagnosis of heterozygous individuals [16]. It is emphasized, however, that even in the case of adequate diagnosis and treatment, factors such as antimicrobial resistance and non-adherence therapy may disrupt 
the patient's conduction, in our report the first cause is the most likely associated with an inherent difficulty in the process infectious. According to Puccini, Ferrarini and Iazzetti [15] bone infections in the pediatric age group should always be treated as severe and, even when appropriate therapy can still evolve with sequelae.

There is no specific treatment and, therefore, the approach to reduce mortality and morbidity of the disease should be based on the prevention of complications such as pain, infections, splenic sequestration and multiprofessional follow-up with early diagnosis through neonatal screening [17] [18] included in the National Neonatal Screening Program (NNSP), through Administrative Rule $\mathrm{n}^{\circ}$ 822/01, of the Brazilian Ministry of Health [9] [19].

\section{Final Considerations}

Hemoglobinopathy SC is a disease that can present high morbidity, especially when it comes to osteoarticular infections although not very high prevalence. Thus, osteomyelitis and septic arthritis in patients in the pediatric age group should be considered as serious infections that deserve hospitalization and more expressive treatment.

\section{References}

[1] Freitas, L.G.A., et al. (2011) Alterações retinianas apresentadas em pacientes portadores de hemoglobinopatia falciforme atendidos em um Serviço Universitário de Oftalmologia. Arquivos Brasileiros de Oftalmologia, 74, 335-337. https://doi.org/10.1590/S0004-27492011000500005

[2] Melo-Reis, P.R., et al. (2006) A importância do diagnóstico precoce na prevenção das anemias hereditárias. Revista Brasileira de Hematologia e Hemoterapia, 28, 149-152. https://doi.org/10.1590/S1516-84842006000200017

[3] Simon, E., Long, B. and Koyfman, A. (2016) Emergency Medicine Management of Sickle Cell Disease Complications: An Evidence-Based Update. Journal of Emergency Medicine, 51, 370-381. https://doi.org/10.1016/j.jemermed.2016.05.042

[4] Piel, F.B., Simon, I.H., Gupta, S., Weathehall, D. and Williams, T.N. (2013) Global Burden of Sickle Cell Anaemia in Children under Five, 2010-2050: Modelling Based on Demographics, Excess Mortality, and Interventions. PLoS Medicine, 10, e10001484. https://doi.org/10.1371/journal.pmed.1001484

[5] Thame, M.M., Singh-Minott, I., Osmond, C. and Melbourne-Chambers, R.H. (2016) Pregnancy in Sickle Cell-Haemoglobin C (SC) Disease. A Retrospective Study of Birth Size and Maternal Weight Gain. European Journal of Obstetrics, Gynecology, and Reproductive Biology, 203, 16-19. https://doi.org/10.1016/j.ejogrb.2016.05.002

[6] Benites, B.D., Benevides, T.C.L., Valente, I.S., Marques, J.F., Gilli, S.C.O. and Saad, S.T.O. (2016) The Effects of Exchange Transfusion for Prevention of Complications during Pregnancy of Sickle Hemoglobin C Disease Patients. Transfusion, 56, 119 124. https://doi.org/10.1111/trf.13280

[7] Asnani, M.R., Quimby, K.R., Bennett, N.R. and Francis, D.K. (2016) Interventions for Patients and Caregivers to Improve Knowledge of Sickle Cell Disease and Recognition of Its Related Complications. Cochrane Database of Systematic Reviews, 6, CD011175. https://doi.org/10.1002/14651858.cd011175.pub2 
[8] Oteng-Ntim, E., Ayensah, B., Knight, M. and Howard, J. (2014) Pregnancy Outcome in Patients with Sickle Cell Disease in the UK-A National Cohort Study Comparing Sickle Cell Anaemia (HbSS) with HbSC Disease. British Journal of Haematology, 169, 129-137. https://doi.org/10.1111/bjh.13270

[9] Sommer, C.K., Stela, G.A., Wagner Sandrine, C. and Castro Simone, M. (2006) Triagem neonatal para hemoglobinopatias: experiência de um ano na rede de saúde pública do Rio Grande do Sul, Brasil. Cadernos de Saúde Pública, 22, 1709-1714. https://doi.org/10.1590/S0102-311X2006000800019

[10] Azevedo, E.S., Alves, A.F.P., Silva, M.C.B.O., Souza, M.G.F., Lima, A.M.V.M.D. and Azevedo, W. (1980) Distribution of Abnormal Hemoglobins and Glucose-6Phosphate Dehydrogenase Variants in 1200 School Children of Bahia, Brazil. American Journal of Physical Anthropology, 53, 509-512. https://doi.org/10.1002/ajpa.1330530407

[11] Naoum, P.C. (1997) Hemoglobinopatias e Talassemias. Sarvier Ed. Livros Médicos, São Paulo.

[12] Bandeira, F.M.G.C., Leal, M.C., Souza, R.R., Furtado, V.C., Gomes, Y.M. and Marques, N.M. (1999) Características de recém-nascidos portadores de hemoglobina "S" detectados através de triagem em sangue de cordão umbilical. Journal of Pediatrics, 75, 167-171. https://doi.org/10.2223/JPED.292

[13] Santos, L.R.O., da Rocha, S.S., Costa, R.d.S., de Araujo, O.D., Oliveira, F.B.M. and Barros, R.S. (2012) Family Care for Children with Sickle Cell Disease. Revista de Enfermagem da UFPI, 1, 124-127.

[14] Squiers, J.J., Edwards, A.G., Parra, A. and Hofmann, S.L.J. (2016) Acute Splenic Sequestration Crisis in a 70-Year-Old Patient with Hemoglobin SC Disease. Journal of Investigative Medicine High Impact Case Reports, 4, Article ID: 2324709616638363.

[15] Puccini, P.F., Ferranini, M.A.G. and Iazzetti, A.V. (2012) Osteomielite hematogênica aguda em Pediatria: análise de casos atendidos em hospital universitário. Revista Paulista De Pediatria, 30, 353-358. https://doi.org/10.1590/S0103-05822012000300008

[16] Clark, B.E. and Thein, S.L. (2004) Molecular Diagnosis of Haemoglobin Disorders. Clinical and Laboratory Haematology, 26, 159-176. https://doi.org/10.1111/j.1365-2257.2004.00607.x

[17] Agência Nacional de Vigilância Sanitária (ANVISA) (2002) Manual de diagnóstico e tratamento de doenças falciformes. Ministério da Saúde, Brasília.

[18] Bitarães, E.L., Oliveira, B.M. and Viana, M.B. (2008) Adesão à antibioticoterapia profilática em crianças com anemia falciforme: Um estudo prospectivo. Journal of Pediatrics, 84, 316-322. https://doi.org/10.1590/s0021-75572008000400006

[19] Silva, W.S., Oliveira, R.F., Ribeiro, S.B., da Silva, I.B., de Araújo, E.M. and Baptista, A.F. (2016) Screening for Structural Hemoglobin Variants in Bahia, Brazil. International Journal of Environmental Research and Public Health, 13, 225. https://doi.org/10.3390/ijerph13020225 
Submit or recommend next manuscript to SCIRP and we will provide best service for you:

Accepting pre-submission inquiries through Email, Facebook, LinkedIn, Twitter, etc. A wide selection of journals (inclusive of 9 subjects, more than 200 journals)

Providing 24-hour high-quality service

User-friendly online submission system

Fair and swift peer-review system

Efficient typesetting and proofreading procedure

Display of the result of downloads and visits, as well as the number of cited articles Maximum dissemination of your research work

Submit your manuscript at: http://papersubmission.scirp.org/

Or contact health@scirp.org 